\title{
Chemical and Mineral Bio-availability Composition of Indigenous Vegetable Sauces: Implication for Type 2 Diabetes Mellitus
}

\author{
Joy Adaku Chibuzo Amadi ${ }^{1,}$, , Asinobi Chinagorom Onyemaechi ${ }^{1}$, Okeke Phenomena Ngozi $^{1}$, \\ Ndukwu Sylvia Ogechi ${ }^{1}$, Nwachukwu Chijioke Nnaemeka ${ }^{2}$, Edward Uzoamaka ${ }^{3}$ \\ ${ }^{1}$ Department of Nutrition and Dietetics, Imo State University, Owerri, Nigeria \\ ${ }^{2}$ Department of Food Science and Technology, Imo State University, Owerri, Nigeria \\ ${ }^{3}$ Department of Medical Laboratory Science, Imo State University, Owerri, Nigeria
}

Email address:

Joyevans2020@yahoo.com (J. A. C. Amadi)

${ }^{*}$ Corresponding author

\section{To cite this article:}

Joy Adaku Chibuzo Amadi, Asinobi Chinagorom Onyemaechi, Okeke Phenomena Ngozi, Ndukwu Sylvia Ogechi, Nwachukwu Chijioke Nnaemeka, Edward Uzoamaka. Chemical and Mineral Bio-availability Composition of Indigenous Vegetable Sauces: Implication for Type 2 Diabetes Mellitus. International Journal of Diabetes and Endocrinology. Vol. 4, No. 4, 2019, pp. 90-97. doi: 10.11648/j.ijde.20190404.11

Received: August 14, 2019; Accepted: September 27, 2019; Published: October 15, 2019

\begin{abstract}
Chemical and mineral bioavailability composition of indigenous vegetable sauces: implication for type 2 diabetes mellitus was evaluated. Vegetables and ingredients for sauce preparation were purchased from Relief market Owerri, Imo State. The vegetables were used in preparation of okra sauce, African spinach sauce and lettuce sauce. It was oven-dried at $50^{\circ} \mathrm{C}$ for 14 hours. The sauces were analyzed for proximate, minerals, vitamin, antinutrient while mineral to antinutrient ratios was calculated using standard methods. Statistical analysis using Statistical Product for Service Solution (SPSS) was used to determine one way Analysis of variance (ANOVA) to separate the means while Turkey test model was used to test significant difference. P-value at 0.05 was considered significant. Significant difference was observed only in dietary fibre ( $<<0.05$ ). Mineral composition showed significant $(\mathrm{p}<0.05)$ differences in African spinach sauce for sodium, calcium, magnesium, potassium, iron, zinc and manganese and only highest in phosphorus for lettuce sauce. Tannin was significantly highest in lettuce sauce and African spinach sauce, for phytate and oxalate in African spinach sauce. All the minerals studied showed high bioavailability. Vitamin composition was significantly $(\mathrm{p}<0.05)$ different among the vegetable sauces in all the water soluble vitamin studied but was only significant $(\mathrm{p}<0.05)$ for vitamin $\mathrm{D}$ for all the fat soluble vitamins in okra sauce. Consumption of these vegetable sauces should be encouraged especially among the type 2 diabetic subjects.
\end{abstract}

Keywords: Vegetable Sauces, Indigenous, Type 2 Diabetes Mellitus, Mineral Bioavailability

\section{Introduction}

Type 2 diabetes mellitus is a consequent of insulin secretion, insulin action or both imbalances which result in impaired function in carbohydrate, lipid and protein metabolism $[1,2]$. High blood glucose concentration leads to oxidative stress through the over production of reactive oxygen species (ROS) thereby predisposing victims to diabetic complications [3, 4]. Effective hyperglycemia control is for reducing the risk of vascular complications [5, 6]. Diabetic patients need nutrition recommendations that are supported with scientific evidence and that can be easily understood and translated into everyday life. In order to achieve the goals and objectives of dietary therapy, it is important that diabetic patients are provided with dietary guideline appropriate to their cultural background such as availability and affordability of food types.

Vegetables contains little energy, protein of low biological value, but high in vitamins, minerals, fibre and bioactive components which helps in the prevention and management of diet related chronic diseases [7]. In Nigeria, vegetable consumption is below the recommended dietary intake (RNI) despite its recognition as an important food component to 
reduce hidden hunger from inadequate micronutrient intake $[8,9]$. Consumption of vegetable has been reported to be beneficial in reducing metabolic diseases, blood cholesterol reduction, prevents bowel diseases and improves glucose intolerance due to its dietary fibre [10]. However, there is paucity of study on incorporation of okra, African spinach and lettuce vegetables in sauce or soup preparation. Evaluation of indigenous vegetable sauces using African spinach, okra and lettuce is rare. Therefore, the knowledge of its nutrient, antinutrient and mineral bioavailability composition would help in its consumption.

\section{Materials and Methods}

\subsection{Procurement of Materials}

Vegetables and ingredients for sauce preparation were purchased from Relief market Owerri, Imo State. The vegetables were identified at Crop Department, Faculty of Agriculture and Veterinary Medicine, Imo State University, Nigeria.

\subsection{Recipe for Vegetable Sauces}

Recipe for the vegetable sauces was designed to accommodate the same ingredients and method of cooking. Preparation was carried out at Food Laboratory, Nutrition and Dietetics Department, Imo State University.

a. Okra sauce preparation

Table 1. Okra sauce preparation

\begin{tabular}{ll}
\hline Ingredients & Quantity \\
\hline Okra pods & $1000 \mathrm{~g}$ \\
Sliced onion & $200 \mathrm{~g}$ \\
Palm oil & $15 \mathrm{~g}$ \\
Milled crayfish & $150 \mathrm{~g}$ \\
Milled fresh pepper & $15 \mathrm{~g}$ \\
Salt & $5 \mathrm{~g}$ \\
Sliced tomatoes & $200 \mathrm{~g}$ \\
Water & $1500 \mathrm{ml}$ \\
\hline
\end{tabular}

Method of cooking okra sauce

Okra pods were washed and sliced into small size and was prepared separately. The pot was allowed to dry, the oil and onion was added immediately (it should not be allowed to heat before adding the onion so that the oil will not be hydrogenated). The sliced tomatoes was be added and was allowed to steam for 3 minutes. Crayfish, pepper, salt, and water was added and allowed to stem for 2 minutes. Okra and water was added and allowed to steam for 5 minutes. It was removed from heat and allowed to cool. The okra sauce was oven dried at $50^{\circ} \mathrm{C}$ for 14 hours.

b. African spinach sauce preparation

Table 2. African spinach sauce preparation.

\begin{tabular}{ll}
\hline Ingredients & Quantity \\
\hline African spinach leaves & $1000 \mathrm{~g}$ \\
Sliced onion & $200 \mathrm{~g}$ \\
Palm oil & $15 \mathrm{~g}$ \\
Milled crayfish & $150 \mathrm{~g}$ \\
\hline
\end{tabular}

\begin{tabular}{ll}
\hline Ingredients & Quantity \\
\hline Milled fresh pepper & $15 \mathrm{~g}$ \\
Salt & $5 \mathrm{~g}$ \\
Sliced tomatoes & $200 \mathrm{~g}$ \\
Water & $150 \mathrm{ml}$ \\
\hline
\end{tabular}

Method of cooking African spinach sauce

African spinach leaves were washed and sliced into small sizes and was prepared separately. The pot was allowed to dry, the oil and onion was added immediately (it should not be allowed to heat before adding the onion so that the oil will not be hydrogenated). The sliced tomatoes was be added and was allowed to steam for 3 minutes. Crayfish, pepper, salt, and water was added and allowed to stem for 2 minutes. African spinach vegetables and water was added and allowed to steam for 2 minutes. It was removed from heat and allowed to cool. The African spinach sauce was oven dried at $50^{\circ} \mathrm{C}$ for 14 hours.

c. Lettuce sauce preparation

Table 3. Lettuce sauce preparation.

\begin{tabular}{ll}
\hline Ingredients & Quantity \\
\hline Lettuce leaves & $1000 \mathrm{~g}$ \\
Sliced onion & $200 \mathrm{~g}$ \\
Palm oil & $15 \mathrm{~g}$ \\
Milled crayfish & $150 \mathrm{~g}$ \\
Milled fresh pepper & $15 \mathrm{~g}$ \\
Salt & $5 \mathrm{~g}$ \\
Sliced tomatoes & $200 \mathrm{~g}$ \\
Water & $150 \mathrm{ml}$ \\
\hline
\end{tabular}

Method of cooking lettuce sauce

Lettuce leaves were washed and sliced into small sizes and was prepared separately. The pot was allowed to dry, the oil and onion was added immediately (it should not be allowed to heat before adding the onion so that the oil will not be hydrogenated). The sliced tomatoes was be added and was allowed to steam for 3 minutes. Crayfish, pepper, salt, and water was added and allowed to stem for 2 minutes. Lettuce leaves was added and allowed to steam for 5 seconds. It was removed from heat and allowed to cool. The lettuce sauce was oven dried at $50^{\circ} \mathrm{C}$ for 14 hours respectively.

\subsection{Chemical Analysis of Vegetables Sauce}

Chemical analysis of the vegetables was conducted for proximate, minerals and anti-nutrients in triplicates using standard methods. The vegetable sauces were also subjected to chemical analysis in triplicates using standard methods to obtain values for proximate, minerals, vitamins, dietary fibre, anti-nutrients and phytochemicals.

(a). Proximate analysis

Proximate composition was analyzed for the vegetable sauces using standard methods by Association of Official Analytical Chemist (AOAC) [11]. Moisture content was determined using hot air oven method. Protein content was determined using micro-kjeldahl method. Ash was determined by weighing $1 \mathrm{~g}$ of each sample into a tarred 
porcelain crucible. This was incinerated at $600^{\circ} \mathrm{C}$ for $6 \mathrm{~h}$ in an ashing muffle furnace until constant weight was obtained. Lipid was estimated by exhaustively extracting a known weight of flour sample with petroleum ether (B.pt $40-60^{\circ} \mathrm{C}$ ) using tecator soxhlet apparatus. Carbohydrate was calculated by difference (100-\%Moisture + Ash + Protein + Fibre+ Fat). All analysis was done in triplicates.

b). Energy value estimation

Energy was determined by the "Atwater factor". The energy value of the each vegetable sauce was calculated by multiplying the values of carbohydrate, fat and protein by 4:9:4 the "Atwater factors" respectively [12].

c). Micronutrient analysis

Mineral analysis was carried out using atomic absorption spectrophotometer according to the method described by Bissessur et al. [13]. Vitamin analysis was carried out using simultaneous analysis of fat and water soluble vitamins as described by Taguchi et al. [14].

d). Anti-nutrient composition of the vegetables

Oxalate content was determined using the permanganate titration method as described by [15]. Phytate was analyzed using AOAC [11]. Tannin was determined as described by Folin-Denis Spectrophotometry by Pearson [16].

e). Determination of mineral bioavailability and molar ratios of anti-nutrients to minerals

The mineral bioavailability was determined as described by David [17] while mineral ratio for $\mathrm{Na} / \mathrm{K}, \mathrm{Ca} / \mathrm{P}, \mathrm{Ca} / \mathrm{K}$ and $\mathrm{Ca} / \mathrm{Mg}$ was determined by dividing the mineral content of the numerator with the mineral content of the denominator. The molar ratio between antinutrient and mineral was obtained after dividing the weight of antinutrient and minerals with their atomic weight (Phytate $=660 \mathrm{~g} / \mathrm{mol}$; oxalate = $88.018 \mathrm{~g} / \mathrm{mol}$; Fe: $55.85 \mathrm{~g} / \mathrm{mol}$ Z $\mathrm{Zn}: 65.35 \mathrm{~g} / \mathrm{mol}$; Ca: 40.08 $\mathrm{g} / \mathrm{mol})[18,19]$.

\subsection{Statistical Analysis}

Statistical Product for Service Solution (IBM SPSS Inc., Chicago Ill) version 23.0 was used in statistical analysis. Descriptive statistics was used in analyzing the means and standard deviation of mineral and antinutrient vegetable sauces. One way analysis of variance (ANOVA) was used to test the significant difference of the different sauces while turkey test model. All statistical analysis was tested at $95 \%$ confidence level $(\mathrm{p}<0.05)$.

\section{Results}

\subsection{Proximate, Dietary Fibre and Energy Composition of Vegetable Sauces}

Table 4 showed the proximate, dietary fibre and energy composition of the vegetable sauces. The vegetable sauces did not differ significantly $(\mathrm{p}>0.05)$ except in dietary fibre, lettuce $(30.26 \mathrm{~g})$ was significantly $(\mathrm{p}<0.05)$ higher compared to okra and African spinach sauces. Moisture content ranged from $8.10 \%$ (lettuce sauce) to $8.48 \%$ (African spinach), protein ranged from $18.74 \%$ (African spinach sauce) to $20.15 \%$ (lettuce sauce), crude fat ranged from $14.40 \%$ (African spinach sauce) to 15.22 (okra sauce), crude fibre ranged from $11.20 \%$ (lettuce sauce) to $13.22 \%$ (okra sauce), carbohydrate ranged from 34.29\% (okra sauce) to $37.15 \%$ (African spinach sauce) and energy ranged from $173.79 \mathrm{kcal}$ (African spinach sauce) to $296.88 \mathrm{kcal}$ (okra sauce).

Table 4. Proximate, dietary fibre and energy composition of vegetable sauces.

\begin{tabular}{llll}
\hline Proximate (\%) & Lettuce & Okra & African spinach \\
\hline Moisture & $8.10^{\mathrm{a}} \pm 0.57$ & $8.44^{\mathrm{a}} \pm 0.65$ & $8.48^{\mathrm{a}} \pm 0.21$ \\
Protein & $20.15^{\mathrm{a}} \pm 0.09$ & $19.75^{\mathrm{a}} \pm 0.01$ & $18.74^{\mathrm{a}} \pm 0.16$ \\
Crude fat & $8.82^{\mathrm{a}} \pm 0.13$ & $9.08^{\mathrm{a}} \pm 0.06$ & $9.33^{\mathrm{a}} \pm 0.12$ \\
Ash & $14.82^{\mathrm{a}} \pm 0.14$ & $15.22^{\mathrm{a}} \pm 0.58$ & $14.40^{\mathrm{a}} \pm 0.24$ \\
Crude fibre & $11.20^{\mathrm{a}} \pm 0.03$ & $13.22^{\mathrm{a}} \pm 0.09$ & $11.90^{\mathrm{a}} \pm 0.16$ \\
Carbohydrate & $36.91^{\mathrm{a}} \pm 0.82$ & $34.29^{\mathrm{a}} \pm 0.77$ & $37.15^{\mathrm{a}} \pm 0.39$ \\
Energy (kcal/100g) & $290.11^{\mathrm{a}} \pm 0.23$ & $296.88^{\mathrm{a}} \pm 0.31$ & $173.79^{\mathrm{a}} \pm 0.41$ \\
Dietary fibre $(\mathrm{g})$ & $30.26^{\mathrm{b}} \pm 0.01$ & $20.39^{\mathrm{b}} \pm 0.14$ & $20.25^{\mathrm{a}} \pm 0.02$ \\
\hline
\end{tabular}

Values are means $\pm \mathrm{SD}$ (Standard) of triplicate determination. Mean values of different superscript in the same row are significant are $\mathrm{p}<0.05$.

\subsection{Mineral Composition of Vegetable Sauces}

Table 5 showed the mineral composition of lettuce, okra and African spinach sauces. Sodium was significantly $(\mathrm{p}<0.05)$ in African spinach $(3.74 \pm 0.34 \mathrm{mg} / 100 \mathrm{~g})$ and calcium $(5.3 \pm 0.21 \mathrm{mg} / 100 \mathrm{~g}), \quad$ magnesium $(3.18 \pm 0.12 \mathrm{mg} / 100 \mathrm{~g})$, iron $(7.61 \pm 0.04 \mathrm{mg} / 100 \mathrm{~g})$, potassium $(5.22 \pm 0.01 \mathrm{mg} / 100 \mathrm{~g})$, and zinc $(7.24 \pm 0.01 \mathrm{mg} / 100 \mathrm{~g})$ was significantly $(\mathrm{p}<0.05)$ higher in African spinach sauce. Selenium and chromium had similar values in the vegetable sauces, phosphorous $(6.12 \pm 0.01)$ was significantly $(\mathrm{p}<0.05)$ higher in lettuce while manganese $(0.92 \pm 0.03)$ was significantly $(\mathrm{p}<0.05)$ higher in African spinach.

Table 5. Mineral composition of vegetable sauces.

\begin{tabular}{llll}
\hline Minerals (mg/100g) & Lettuce & Okra & African spinach \\
\hline Sodium & $3.68^{\mathrm{a}} \pm 0.02$ & $3.12^{\mathrm{b}} \pm 0.04$ & $3.74^{\mathrm{a}} \pm 0.34$ \\
Calcium & $1.68^{\mathrm{b}} \pm 0.03$ & $5.22^{\mathrm{a}} \pm 0.11$ & $5.31^{\mathrm{a}} \pm 0.21$ \\
Magnesium & $1.14^{\mathrm{c}} \pm 0.25$ & $1.94^{\mathrm{b}} \pm 0.23$ & $3.18^{\mathrm{a}} \pm 0.12$ \\
Potassium & $3.70^{\mathrm{b} \pm 0.11}$ & $3.26^{\mathrm{b}} \pm 0.17$ & $5.22^{\mathrm{a}} \pm 0.01$ \\
Iron & $1.49^{\mathrm{b} \pm 0.23}$ & $1.23^{\mathrm{c}} \pm 0.13$ & $7.61^{\mathrm{a}} \pm 0.04$ \\
Zinc & $4.74^{\mathrm{c}} \pm 0.43$ & $5.16^{\mathrm{b}} \pm 0.12$ & $7.24^{\mathrm{a}} \pm 0.01$ \\
Selenium $(\mu g / 100 \mathrm{~g})$ & $0.63^{\mathrm{a}} \pm 0.32$ & $0.58^{\mathrm{a}} \pm 0.11$ & $0.54^{\mathrm{a}} \pm 0.01$ \\
Phosphorous & $6.12^{\mathrm{a}} \pm 0.01$ & $4.46^{\mathrm{b}} \pm 0.01$ & $4.32^{\mathrm{b}} \pm 0.01$ \\
Manganese & $0.23^{\mathrm{c} \pm 0.02}$ & $0.72^{\mathrm{b}} \pm 0.02$ & $0.92^{\mathrm{a}} \pm 0.03$ \\
Chromium $(\mu g / 100 \mathrm{~g})$ & $0.02^{\mathrm{a}} \pm 0.01$ & $0.01^{\mathrm{a}} \pm 0.01$ & $0.01^{\mathrm{a}} \pm 0.01$ \\
\hline
\end{tabular}

Values are means $\pm \mathrm{SD}$ (Standard) of triplicate determination. Mean values of different superscript in the same row are significant are $\mathrm{p}<0.05$ 


\subsection{Anti-nutrients Composition of Vegetable Sauces}

Table 6 showed the anti-nutrients composition of vegetable sauce. Tannin $(0.16 \pm 0.07 \mathrm{mg} / 100 \mathrm{~g})$ and phytate
$(1.22 \pm 0.04 \mathrm{mg} / 100 \mathrm{~g})$ were higher in African spinach sauce, lettuce sauces was higher in oxalate $(0.51 \pm 0.15$ $\mathrm{mg} / 100 \mathrm{~g})$.

Table 6. Anti-nutrients composition of vegetable sauces.

\begin{tabular}{llll}
\hline Anti-nutrients $(\mathbf{m g} / \mathbf{1 0 0 g})$ & Lettuce & Okra & African spinach \\
\hline Tannin & $0.13^{\mathrm{a}} \pm 0.23$ & $0.09^{\mathrm{b}} \pm 0.58$ & $0.16^{\mathrm{a}} \pm 0.07$ \\
Phytate & $0.60^{\mathrm{c}} \pm 0.06$ & $0.86^{\mathrm{b}} \pm 0.22$ & $0.97^{\mathrm{a}} \pm 0.04$ \\
Oxalates & $0.18^{\mathrm{c}} \pm 0.15$ & $0.36^{\mathrm{b}} \pm 0.01$ & $0.65^{\mathrm{a}} \pm 0.01$ \\
\hline
\end{tabular}

Values are means $\pm \mathrm{SD}$ (Standard) of triplicate determination. Mean values of different superscript in the same row are significant are $\mathrm{p}<0.05$

\subsection{Mineral Bioavailability and Molar Ratio of Minerals To Anti-Nutrient of Vegetable Sauces}

Mineral bioavailability and molar ratio of minerals to anti-nutrients of the vegetable sauces were presented on Table $4 . \mathrm{Na} / \mathrm{K}$ mineral bioavailability was highest for okra $(0.9 \pm 0.02)$ but significantly lower in lettuce sauce and African spinach sauce, $\mathrm{Ca} / \mathrm{P}(0.3 \pm 0.01), \mathrm{Ca} / \mathrm{K}(0.3 \pm 0.01)$ and $\mathrm{Ca} / \mathrm{Mg}(1.5 \pm 0.01)$ were all significantly lower in lettuce. Molar ratio of minerals to anti-nutrients showed that $[\mathrm{Phy}] /[\mathrm{Zn}], \quad[\mathrm{Phy}] /[\mathrm{Fe}]$ and $[\mathrm{Oxa}] /[\mathrm{Ca}]$ were significantly $(\mathrm{p}<0.05)$ lower in lettuce $(0.050,0.012$, 0.012 ) respectively, $[\mathrm{Phy}] /[\mathrm{Ca}]$ was lower in African spinach while Phytate*Ca: $\mathrm{Zn}$ was significantly $(\mathrm{p}<0.05)$ lower $(0.0005 \mathrm{mmol} / \mathrm{g})$ in lettuce.

Table 7. Mineral bioavailability and molar ratio of minerals to anti-nutrients of vegetablesauces.

\begin{tabular}{llll}
\hline Parameters & Lettuce & Okra & African spinach \\
\hline $\mathrm{Na} / \mathrm{K}$ & $0.9^{\mathrm{a}} \pm 0.01$ & $0.9^{\mathrm{a}} \pm 0.02$ & $0.71^{\mathrm{a}} \pm 0.03$ \\
$\mathrm{Ca} / \mathrm{P}$ & $0.3^{\mathrm{c}} \pm 0.01$ & $2.4^{\mathrm{a}} \pm 0.12$ & $1.7^{\mathrm{b}} \pm 0.12$ \\
$\mathrm{Ca} / \mathrm{K}$ & $0.8^{\mathrm{b}} \pm 0.02$ & $1.7^{\mathrm{a}} \pm 0.03$ & $1.5^{\mathrm{a}} \pm 0.05$ \\
$\mathrm{Ca} / \mathrm{Mg}$ & $1.5^{\mathrm{b}} \pm 0.01$ & $2.6^{\mathrm{a}} \pm 0.01$ & $1.7^{\mathrm{b}} \pm 0.03$ \\
{$[\mathrm{Phy}] /[\mathrm{Zn}]$} & $0.050^{\mathrm{c}} \pm 0.01$ & $0.128^{\mathrm{a}} \pm 0.01$ & $0.120^{\mathrm{b}} \pm 0.01$ \\
{$[\mathrm{Phy}] /[\mathrm{Ca}]$} & $0.024^{\mathrm{a}} \pm 0.02$ & $0.007^{\mathrm{b}} \pm 0.01$ & $0.006^{\mathrm{b}} \pm 0.01$ \\
{$[\mathrm{Oxa}] /[\mathrm{Ca}]$} & $0.012^{\mathrm{b}} \pm 0.01$ & $0.038^{\mathrm{a}} \pm 0.01$ & $0.038^{\mathrm{a}} \pm 0.02$ \\
{$[\mathrm{Phy}] /[\mathrm{Fe}]$} & $0.012^{\mathrm{c}} \pm 0.01$ & $0.045^{\mathrm{b}} \pm 0.02$ & $0.333^{\mathrm{a}} \pm 0.01$ \\
\hline
\end{tabular}

Values are means $\pm \mathrm{SD}$ (Standard) of triplicate determination. Mean values of different superscript in the same row are significant are $\mathrm{p}<0.05$

\subsection{Vitamin Composition of Vegetable Sauces}

Table 8 showed the vitamin composition of the vegetable sauces. Water soluble vitamins; vitamin $\mathrm{B}_{1}(0.023 \pm 0.21 \mathrm{mg} / 100 \mathrm{~g})$, $\mathrm{B}_{2}(0.034 \pm 0.11 \mathrm{mg} / 100 \mathrm{~g})$ and $\mathrm{C}(74.805 \pm 0.21 \mathrm{mg} / 100 \mathrm{~g})$ were higher in lettuce sauce. However, lettuce and okra sauces had the same vitamin $B_{5}(0.036 \pm 0.02 \mathrm{mg} / 100 \mathrm{~g})$ content. Vitamin $B_{3}$
$(0.032 \pm 0.02 \mathrm{mg} / 100 \mathrm{~g}), \quad \mathrm{B}_{6} \quad(0.02 \pm 0.11 \mathrm{mg} / 100 \mathrm{~g}) \quad$ and $\quad \mathrm{B}_{9}$ $(0.01 \pm 0.01 \mathrm{mg} / 100 \mathrm{~g})$ were higher in African spinach. On the other hand, fat soluble vitamin showed that okra sauce was higher in vitamin D $(0.111 \pm 0.0 \mathrm{mg} / 100 \mathrm{~g})$ and vitamin $\mathrm{E}$ $(3.32 \pm 0.02 \mathrm{mg} / 100 \mathrm{~g})$ while vitamin A was higher in African spinach $(0.943 \pm 0.02 \mathrm{mg} / 100 \mathrm{~g})$.

Table 8. Vitamin composition of vegetable sauces.

\begin{tabular}{llll}
\hline Vitamin composition $\mathbf{( m g / 1 0 0 g})$ & Lettuce sauce & Okra sauce & African spinach sauce \\
\hline Water soluble vitamins & & & \\
Vitamin $B_{1}$ & $0.023^{\mathrm{a}} \pm 0.21$ & $0.020^{\mathrm{a}} \pm 0.20$ & $0.009^{\mathrm{b}} \pm 0.02$ \\
Vitamin $\mathrm{B}_{2}$ & $0.034^{\mathrm{a}} \pm 0.11$ & $0.029^{\mathrm{a}} \pm 0.01$ & $0.004^{\mathrm{b}} \pm 0.01$ \\
Vitamin $\mathrm{B}_{3}$ & $0.022^{\mathrm{b}} \pm 0.13$ & $0.018^{\mathrm{a}} \pm 0.01$ & $0.032^{\mathrm{a}} \pm 0.02$ \\
Vitamin $\mathrm{B}_{5}$ & $0.036^{\mathrm{a}} \pm 0.02$ & $0.036^{\mathrm{a}} \pm 0.03$ & $0.02^{\mathrm{b}} \pm 0.01$ \\
Vitamin $\mathrm{B}_{6}$ & $0.012^{\mathrm{a}} \pm 0.11$ & $0.009^{\mathrm{b}} \pm 0.04$ & $0.02^{\mathrm{a}} \pm 0.11$ \\
Vitamin $\mathrm{B}_{9}$ & $0.006^{\mathrm{a}} \pm 0.03$ & $0.004^{\mathrm{b}} \pm 0.01$ & $0.01^{\mathrm{a}} \pm 0.01$ \\
Vitamin C & $74.805^{\mathrm{a}} \pm 0.21$ & $72.573^{\mathrm{a}} \pm 0.24$ & $29.76^{\mathrm{b}} \pm 0.23$ \\
Fat soluble vitamins & & & \\
Vitamin A & $0.087^{\mathrm{b}} \pm 0.01$ & $0.943^{\mathrm{a}} \pm 0.02$ & $0.096^{\mathrm{a}} \pm 0.12$ \\
Vitamin D & $0.0003^{\mathrm{b}} \pm 0.01$ & $0.111^{\mathrm{a}} \pm 0.01$ & $0.0002^{\mathrm{b}} \pm 0.01$ \\
Vitamin E & $3.09^{\mathrm{a}} \pm 0.21$ & $3.32^{\mathrm{a}} \pm 0.02$ & $2.947^{\mathrm{a}} \pm 0.01$ \\
Vitamin K & $0.01^{\mathrm{a}} \pm 0.11$ & $0.01^{\mathrm{a}} \pm 0.02$ & $0.01^{\mathrm{a}} \pm 0.01$ \\
\hline
\end{tabular}

Values are means $\pm \mathrm{SD}$ (Standard) of triplicate determination. Mean values of different superscript in the same row are significant are $\mathrm{p}<0.05$. 


\section{Discussion}

\subsection{Proximate, Dietary Fibre and Energy Composition of Vegetable Sauces}

Moisture contents of the vegetable sauces ranged from $8.10 \%$ to $8.48 \%$, this observation shows that the moisture content was low and disagrees with Ponka et al. [20]; Kayode et al. [21] and Davidson et al. [22]. This could be because the vegetable sauces were analyzed on dry basis in order to achieve a homogenous sample and this is an indication that the shelf life of the vegetable sauces was high. Protein content of the vegetable sauces was highest in African spinach sauce $(20.15 \%)$ than okra sauce $(19.75 \%)$ and lettuce sauce $(18.74 \%)$ though not significantly $(p>0.05)$. In the present study, recipe was formulated so as to accommodate people from low socioeconomic class because only crayfish was used as animal source of protein while other sources of protein used were from other vegetables. The study by Ponka et al. [20] also used crayfish as animal source of protein. The use of animal protein such as red and processed meat has been reported to increase the susceptibility to T2DM [23]. Protein content of the vegetable sauces was consistent with Sabitha et al. [24]; Ukegbu and Okebugwu [25] and Davidson et al. [22]. Protein diets especially plant based has been shown to promote glucose homeostasis and is not associated with T2DM risk [26, 27] but animal protein especially red and processed meat promotes insulin resistance and increases gluconeogenesis [28].

The vegetable sauces contained high ash content which is an indication that it could be a useful mineral source in meals. Ash content of the vegetable sauces was significantly $(p<0.05)$ higher in lettuce sauce than other sauces. Dietary fibre content was high in the vegetable sauces though it was significantly $(\mathrm{p}<0.05)$ higher in lettuce sauce $(30.26 \mathrm{~g})$ than okra sauce $(20.39 \mathrm{~g})$ and African spinach sauce $(20.25 \mathrm{~g})$. This may be explained by the dietary fibre content of the raw vegetables used which was highest in lettuce sauces. Also, the high dietary fibre content of the vegetable sauces could be the ingredients used in the sauces preparation which include tomatoes, onion, fresh pepper (all vegetables). In diabetic management, dietary recommendation of $25-35 \mathrm{~g}$ /day is allowed in proportion to patient's caloric intake. This means that the sauces will provide significant amount of dietary fibre to the meals when taken. Diet high in dietary fibre decreases insulin resistances because, dietary fibre affects insulin secretion and action indirectly by its effects on gut motility and transit, gastrointestinal hormone secretion, colon fermentation which yield short chain fatty acids that inhibits hepatic gluconeogenesis [29].

According to Caricilli and Saad [30], disruption in the bacterial environment of the gut is associated with insulin resistance and metabolic problems. Dietary fibre especially resistant starch has been reported to decrease post-prandial glucose and insulin responses, improves insulin sensitivity, lower triglycerides and HDL, increases satiety and reduces fat storage (Higgins, 2004).Dietary fat especially saturated and trans-fat is associated with an increased risk for several chronic diseases including type 2 diabetes mellitus and hypertension. The study observed that fat content of the vegetable sauce was relatively low ranging from $8.82 \%$ (lettuce sauce) to $9.33 \%$ (African spinach sauce). Fat slows down the rate of digestion in the intestine which gives a low glycemic index when compared with similar food with little or without fat [31]. However, Amadi et al. [32] reported that these vegetable sauces (lettuce, African spinach and okra sauces) fed to normoglycemic subjects gave a low glycemic response irrespective of the fact that the fat content of the vegetable sauces was low. The implication of the study was that the recipe in the present study was designed in a way that fat contribution from palm oil was small which corresponds to the aim of diabetic management that is to reduce saturated fatty acids, trans-fatty acid and cholesterol intake so as to limit the risk of cardiovascular diseases. Also, the palm oil was not allowed to hydrogenate which may subsequently lead to saturation. Hydrogenation process changes good fats into cholesterol-raising saturated and trans-fats. The recipe used support previous study that in order to have good diabetic control, meat, high fat, dairy products and oils should be reduced in meals [33]. Diabetic patients already have high risk of developing high levels of fats in their heart and blood vessels which will predispose them to cardiovascular diseases and fats also delay the action of insulin by getting glucose into the cells [34]. Therefore, intake of fat among this population should be monitored. Energy content of the sauces was comparable to other literatures on dish preparation [35-37]. The vegetable sauce will accommodate little of the energy need of adult diabetic patients. The low energy content can be appreciated by the low fat content of the sauces.

\subsection{Mineral Composition of Vegetable Sauces}

Calcium content was significantly $(\mathrm{p}<0.05)$ highest in African spinach sauce $(5.31 \mathrm{mg} / 100 \mathrm{~g})$ and okra sauce $(5.22 \mathrm{mg} / 100 \mathrm{~g})$ than lettuce sauce $(1.68 \mathrm{mg} / 100 \mathrm{~g})$. The calcium content of the vegetable sauces will be bioavaliable because calcium to phytate, calcium to potassium and calcium to magnesium ratios were within the recommended limit. The implication of the study was that calcium in the vegetable sauces will be involved in the regulation of energy metabolism thereby maintaining good glucose control among diabetic subjects. Adequate calcium diets tend to reduce adipose tissue accretion and weight gain during the periods of overconsumption and increase fat breakdown to preserve thermogenesis during energy restriction, thereby accelerating weight loss and weight control is one of the lifestyle modifications in the management of diabetics among the diabetic patients. Magnesium content of the vegetable sauces was significantly $(\mathrm{p}<0.05)$ highest in African spinach sauce $(3.18 \mathrm{mg} / 100 \mathrm{~g})$. Magnesium in the vegetable sauces will act as a modulatory agent for glucose transport in the cells and will also be involved in metabolic pathways. Therefore the deficiency of magnesium will deter glucose metabolism [38]. Magnesium content in the vegetable sauces will improve insulin sensitivity and delay the onset of complication of diabetes mellitus like cardiovascular disease. This is in 
tandem with Barbagallo and Dominguez [39]. Another important benefit of the vegetable sauces is that it will prevent further oxidative damage in the system of diabetic subjects because magnesium is a component of free radical scavenger super oxide dismutase (SOD).

Zinc content was significantly $(\mathrm{p}<0.05)$ higher in African spinach sauce $(7.24 \mathrm{mg} / 100 \mathrm{~g})$ than other vegetables. The vegetable sauces will provide about $90 \%$ recommended nutrient intake (RNI) of adults. Phytate: Calcium ratio and Phytate*Calcium: Zinc ratio of the vegetable sauces was $<1$ which indicates that zinc will be readily absorbed when consumed. The implication of the study was that zinc from the vegetable sauces will be bioavaliable and provide the needed mechanism in maintaining glucose homeostasis by being involved carbohydrate and lipid metabolism because zinc is a co-factor. This will enhance production and secretion of insulin in diabetic patients. Interestingly, zinc content of the vegetables will be readily absorbed when consumed because the protein content $(18.74 \%$ to $20.15 \%)$ of the vegetable sauces was also high. The reason was that increased dietary protein intake leads to increased zinc intake [40]. Also, adequate zinc status reduces free radicals that cause nephropathy, neuropathy and retinopathy in diabetic condition [41].

Chromium content of the vegetable sauces was very low ranging from $0.01 \mathrm{mg} / 100 \mathrm{~g}$ (okra and African spinach sauces) to $0.02 \mathrm{mg} / 100 \mathrm{~g}$ (lettuce sauce) and could explain the fact that vegetables are not good sources of chromium. However, the chromium content of the vegetable sauces would provide the recommended nutrient intake (RNI) of adults by $20 \%$ (20 to $50 \mu \mathrm{g})$. Chromium in the vegetable sauces will enhance insulin sensitivity and good glycemic control. This is supported by Castello et al. [42]. The vegetable sauces had similar manganese values though the values $(0.23 \mathrm{mg} / 100 \mathrm{~g}$ to $0.92 \mathrm{mg} / 100 \mathrm{~g}$ ) were low, they can provide about $10 \%$ RNI. This is consistent with Manson [43] which stated that vegetables contain about $0.2 \mathrm{mg}$ of manganese. The implication of the study was that taking only these vegetable sauces would not provide diabetic subjects with the recommended nutrient intake of manganese. This means that dietary diversification is paramount. This is because manganese usefulness has been implicated in carbohydrate metabolism. Iron content of the vegetable sauces was significantly $(p<0.05)$ highest in African spinach sauce $(7.61 \mathrm{mg} / 100 \mathrm{~g})$. Iron content in the vegetable sauces would be bioavaliable when consumed because the Phy: Fe ratio was $<1$ as the benchmark for critical cutoff point. Hence iron supplementation helps in reducing oxidative stress. Selenium content of the vegetable sauces was low. This is because green vegetables are not good sources of selenium.

\subsection{Antinutrient Composition of Vegetable Sauces}

The antinutrient of the vegetable sauces were $<1$ in phytate, tannin and oxalate this implies that it will confer a protective role as a phytochemical than binding with minerals in order to hinder absorption of minerals like iron, zinc and calcium thus make it unavailable to the body. The values obtained in the present study were below the critical limit [44].

\subsection{Mineral Bioavailability and Molar Ratio of Minerals to Anti-nutrient in Vegetable Sauces}

The present study observed that the mineral ratio of $\mathrm{Na}$ : K was $<1$ for the three vegetable sauces which is in accordance with the recommended ratio. This is because sodium and potassium are very important in maintaining electrolyte homeostasis. Diabetic patients lose a lot of electrolyte to polyuria, the consumption of these vegetables may ameliorate the problem of dehydration experienced among this population. Monitoring $\mathrm{Na} / \mathrm{K}$ ratio in food materials is important for the prevention of high blood pressure especially among the diabetics who may develop chronic complication. This study suggests that the three vegetable sauces may help in preventing or managing hypertension among diabetic subjects.

The molar ratio of mineral to anti-nutrients among the three vegetables studied shows that they are all $<1$. According to WHO the cut-off for phytic acid to zinc mole ratio was outlined as $\geq 15$ (10-15\%: low bioavailability), 5-15 (30-35\%: medium bioavailability) and $<5$ (50-55\%: high bioavailability). This means that the vegetable sauces would be well absorbed in the human system because it falls within the high bioavailability. Also, the dietary calcium content may affect the phytate: zinc molar ratio because of the kinetic synergism that exists between calcium and zinc ions in Calcium: Zinc: Phytate complex which is less soluble than phytate complexes formed by either of the ions alone [44]. In a study reported by Adetuyiet al. [43], they observed that phytate: Zinc*Calcium ratio observed that the three vegetables were below the critical value of $0.5 \mathrm{~mol} / \mathrm{kg}$. The implication was that zinc content of the vegetables sauces would be bioavaliable.

Phytate: calcium ratio of the vegetables was similar and was within the acceptable limit. Calcium bioavailability is decreased by phytic acids content of food materials. Critical molar ratio of Phytate: Calcium of $<0.24$ shows good calcium bioavailability [18]. The present study observed that all the vegetables were $<0.24$ and calcium in the vegetables will not be affected by the phytate content of the vegetables. Oxalate: calcium content was also very small though significantly higher in lettuce. Oxalate can decrease calcium absorption when the ration of Oxalate: Calcium ratio is $>1$ [45]. In the present study, Oxalate: calcium was very low though it was significantly $(\mathrm{p}<0.05)$ higher in okra and African spinach, this means that dietary calcium in the vegetables would be bio-available. Phytate and iron ratio was significantly $(\mathrm{p}<0.05)$ higher in lettuce but was less than the critical value of $<1$. Hurrell et al. [46] reported that ratio as low as 0.2 still affects iron absorption but Siegenberg et al. [47] stated that phytate: iron molar ratio $>0.15$ is an indication of poor iron bioavailability.

\subsection{Vitamin Composition of the Vegetable Sauces and Diabetic Management}

The two prominent vitamins present in the vegetables sauces are vitamin $\mathrm{C}$ and $\mathrm{E}$. Vitamin $\mathrm{C}$ and $\mathrm{E}$ were 
significantly $(\mathrm{p}<0.05)$ highest in lettuce sauce and okra sauce than African spinach sauce. Interestingly, these vitamins act as antioxidants too and are beneficial in diabetic management Vitamin E is an antioxidant, protecting poly unsaturated fatty acids (PUFAs) in membranes and other critical cellular structures from free radicals and products of oxidation. It works with dietary selenium (a cofactor for glutathione peroxides), vitamin $\mathrm{C}$ and enzymatic antioxidants including superoxide dismutase and catalase [42]. Diabetic animals that received vitamin E (2\%) supplementation exhibited a significant reduction in glucose and glycated hemoglobin levels compared with the control groups. This shows a positive effect of this antioxidant on blood glucose. Vitamin $\mathrm{C}$, an antioxidant vitamin, plays an important role in protecting free radical-induced damage. The exact mechanism by which vitamin $\mathrm{C}$ brings about these changes is not known. It is well documented that there is an increased production of damaging free radicals in type 2 diabetic mellitus patients. The protection against such damage can be offered by free radical-scavenging antioxidants like vitamin C. Also, vitamin C content of the vegetable sauces would enhance the absorption of iron content in the vegetable sauces.

\section{Conclusions}

The vegetable sauces contain high protein, dietary fibre, and micronutrient. High mineral bioavailability will be achieved due to the low antinutrient content of the vegetable sauces. The use of these vegetable sauces may be useful in the prevention and management of diet-related chronic diseases like Type 2 diabetes mellitus. Therefore, cultivation and consumption should be encouraged.

\section{References}

[1] Vlad, I. and Pops, A. (2012). Epidemiology of diabetics Mellitus: A current review. Romanian Journal of Diabetics, Nutrition and Metabolism and Disorder; 19: 433.

[2] El-Rabey, H. A., Alseeni, M. N. and Bakhashwami, A. (2017). The Antidiabetic activity of Nigeria savity and propolis on streptozotocin induced diabetics and diabetic nephropathy in male rats. Evidence Based Compliment Alternative Medicine; 54 (3): 96-45.

[3] Al-Malta, A. C. and El-Rebey, H. A. (2015). Antidiabetic effect of low doses of moringa olifera lam seeds on streptozotocin induced diabetics and diabetic nephropathy in male rate biochemical. Research International; 38: 10-40.

[4] Al-rani, N. (2012) oxidative stress, antioxidants and saliva: A Review. Oxidative stress disorder: 303.

[5] Balarcumar, P. (2014). Implication of fundamental signaling Alteration in diabetes mellitus cardiovascular diseases. Indian Biochemistry and Biophysics; 51: 441-446.

[6] Khandouzi, N., Shidfar, F., Rajah, A., Rahideh, T., Hosseni, P. and Taheri, M. (2015). The effects of ginger on fasting blood sugar, Hemoglobin Alc, Apolio protein B, Apolipo protein A-
$\mathrm{L}$ and Malondialdehyde in Type 2 diabetic patients. Iran Journal Pharmacy Research, 14: 131-136.

[7] Udenta, E, A., Ikemefuna C. Obizoba, I. C., and Oluwafemi O. Oguntibeju, O. O. (2014). Anti-Diabetic Effects of Nigerian Indigenous Plant Foods/Diets. In: Antioxidant-Antidiabetic Agents and Human Health. Intech Open Access book Publishers.

[8] Nwamarah, J. U and Otitoju, G. T. O. (2014). Fruit and vegetable consumption pattern and health challenges of elderly ( $\geq 60$ years) staff in the University of Nigeria, Nsukka and Eungu campuses: a case study. Pakistian Journal of Nutrition; 13 (11): 626-630.

[9] Banwat, W. E., Lar, D. A., Dabor, J., Audu, S. and Lass, S. (2012). Knowledge and intake of fruits and vegetable consumption among adult in an urban community in North Central Nigeria. Nigerian Health Journal; 12: 1-9.

[10] Ashaye, O. A. (2010). Effect of processing methods on chemical and consumer acceptability of Kenaf and Corchorus vegetable. Journal of American science; 6 (2), 165-170.

[11] AOAC (2012). Official methods of Analysis of Association of Official Analytical Chemists $19^{\text {th }}$ edition. Washington D. C.

[12] Nielson, S. S. (2010). Food analysis. $\left(4^{\text {th }}\right.$ ed). (S. S. Nielson, Ed.) Nee York, USA: Springer Science Business Media.

[13] Bissessur, V., Goburdhun, D., and Ruggoo, A. (1999). Evaluation of atomic absorption and titrimetry for calcium determination spectrophotometry (ashing, non-ashing) in selected foods. Science and Technology Research Journal; 3: $115-128$.

[14] Taguchi, K., Fukusaki, E., and Bamba, T. (2014). Simultaneous analysis for water- and fat-soluble vitamins by a novel single chromatography technique unifying supercritical fluid chromatography and liquid chromatography. Journal of Chromatograph; 1362: 270-277.

[15] Onwuka, G., I. (2005). Food Analysis and Instrumentation Theory and Practice. Naphtali Print, Lagos, Nigeria: 81-90.

[16] Pearson, D. (1979). The Chemical Analysis of foods. $8^{\text {th }}$ ed. Churchill Livingstone, Edinburg.

[17] David, L. W. (2010). HTMA mineral ratios, a brief discussion of their clinical importance. Trace Elements Newsletter; 21: 115 .

[18] Woldegiorgis A. Z., Abate D., Haki G. D., and Ziegler G. R. (2015). Major, minor and toxic minerals and anti-nutrients composition in edible mushrooms collected from Ethiopia. Food Processing Technology; 6: 134-142.

[19] Igwe, C. U., Ibegbulem, C. O., Nwaogu, L. A., Ujowundu, C. O. and Okwu, G. N. (2013). Calcium, zinc and phytate interrelationship in four lesser-known African seeds processed into food condiments. Journal of Advanced Chemistry; 4 (2): 288-292.

[20] Ponka, R., Fokou, E., Kansci, G., et al. (2014). Recipes. Proximate and mineral composition of some traditional sauces consumed in the far North Region of Cameroon. International Food Research Journal; 21 (4): 1589-1596.

[21] Kayode, O. A., Ozumba, S., Ojeniyi, D. O. et al. (2010). Micronutrient content of selected indigenous soups in Nigeria. Pakistan Journal of Nutrition; 9 (10): 962-965. 
[22] Davidson, G. I., Ene-Obong, H. N. and Chinma, C. E. (2017). Variations in Nutrients composition of most commonly consumed cassava (Manihotesculenta) mixed dishes in SouthEastern Nigeria. Journal of Food Quality: 1-8.

[23] White, D. L. and Collinson, A. (2013). Red meat, dietary heme iron and risk of type 2 diabetes: the involvement of advanced lipoxidation of endproduct. Advances in Nutrition; 4 (4): 403-411.

[24] Sabitha, L., Ramachendram, N. K. R., and Panneerseram, K. (2011). Antidiabetic and antihyperlipidemic potential of AbelmoschusesculentusMonech in Streptozotocin induced diabetic rats. Journal of Pharmacy and Bio Allied Sciences. 3 (3): $397-402$.

[25] Ukaegbu, P. O and Okebugwu, J. O. (2018). Chemical and sensory assessment of UjujuMyrianthusarboreus) leaf and soup. Nigerian Journal of Nutritional Sciences; 39 (1): 50-58

[26] Van Nielen, M., Feskens, E. J. M., Mensink, M., Slujis, I. (2018). Dietary Protein intake and incidence of type 2 diabetes in Europe: The EPIC-InterAct Case-Cohort study; 37 (7): 1854-1862.

[27] Sluijs, I., Beulens, J. W., van der, A. D. L., Spijkerman, A. M. Gribbee, D. E and Van der Schouw, U. T. (2010). Dietary intake of total animal and vegetable protein and risk of type 2 diabetes in the European Prospective Investigation into Cancer and Nutrition (EPIC) -NL Study. Diabetes Care; 33 (1): 43-48

[28] Ke, Q., Chen, C., He, F., Ye, Y., Nai, X., Cai, L. and Xia, M. (2018). Association between dietary protein intake and Type 2 diabetes varies by dietary pattern. Diabetology Metabolic Syndrome; 10: 48-56.

[29] Cani, P. P., Dowever, C., Delzenne, N. M (2004). Inulin-type fructans modulate gastrointestinal peptides involved in appetite regulation (glucagon-like peptide-1 and ghrelin) in rats. Britain Journal of Nutrition; 92: 521-6.

[30] Caricilli, A. M and Saad, M. J. (2013). The role of gut microbiota on insulin resistance. Nutrients; 5 (3): 829-51.

[31] Asinobi, C., Uzoagba, H., Mba-Anyadioha, A. and Nnodim, J. (2016). Glycemic index of some traditional fortified staple meals on the postprandial glucose response of Nigerian undergraduate students: an open-label study. Functional foods in Health and Disease: 6 (7): 414-424.

[32] Amadi, Joy. A. C. and Asinobi, C. O. (2019). Glycemic index and load responses of indigenous vegetable sauces among healthy young female adults. Functional Foods in Health and Disease. In Press.

[33] Garg, A. (2015). Nutritional recommendations for individuals with Diabetes. Endotex. South Dartmouth (MA): MDText. Com. Inc.

[34] Asif, M. (2014). The prevention and control of type 2 diabetics by changing lifestyle and dietary pattern. Journal of Education and Health Promotion; 3: 1-9.
[35] Eleazu, C. O. (2016). The Concept of low glycemic index and glycemic load foods as panacea for type 2 diabetes mellitus; prospects, challenges and solutions. African Health Science; 16 (2): 468-479.

[36] Amadi, Joy A. C. (2017). Glycemic Index of three Cocoyam varieties consumed in Imo State, Nigeria. Journal of Dietitians Association of Nigeria; (8): 96-103.

[37] Kouame, C. A., Kouassi, N. K., Coulibaly, A. et al. (2014). Glycemic index and glycemic load of selected staples based on rice, yam, and cassava commonly consumed in Cote d'Ivoire. Food and Nutrition Science; 5: 308-315.

[38] Gommers, L. M., Hoenderop, J. G., Bindel, R. J. and de Baaij, J. H. (2016). Hypomagnesemia in type 2 diabetes: A vicious circle. Diabetes; 65 (1): 3-13.

[39] Barbagallo, M. and Dominguez, L. J. (2015). Magnesium and type 2 Diabetes. World Journal of Diabetes; 6 (10): 11521162

[40] Song, M. K., Bischoff, D. S., Song, A. m., Uyemura, K. and Yamaguchi, D. T. (2017). Metabolic relationship between diabetes and Alzheimer's disease affected by cyclo (His-Pro) plus zinc treatment. BiochimicaetBiophysciaActa Clinical; 7: 41-54.

[41] Castello, R. B., Dwyer, J. T. and Bailey, R. L. (2016). Chromium supplementation for glycemic control in type 2 diabetes: Limited evidence for effectiveness. Nutrition Reviews; 74 (9): 455-468.

[42] Manson, P. (2007). Dietary supplements. Third edition. Pharmaceutical Press, London.

[43] Adetuyi, F. O., Osagie, A. U., and Adekunle, A. T. (2011). Nutrient, antinutrient, mineral and bioavailability of okra Abelmoschusesculentus (L) moench. American Journal of Food and Nutrition; I: 49-54.

[44] Lopez, P. M., Mora, P. G., Wysocka, W., Maiztegui, B., Alzugaray, M. E., Zoto, H. D., and Borelli, M. I. (2004). Quinolizldine alkaloids isolated from lupines species enhance insulin secretion. European Journal Pharmacology; 504: 139142 .

[45] Frontela, C., Scarino, M. L., Ferruzza, S., Ros, G., and Martinez, C. (2009). Effect of dephytinization on bioavailability of iron, calcium and from infant cereals accessed in the Caco-2 cell model. World Journal Gastroenterology; 28; 1977-1984.

[46] Hurrel, R. F., Reddy, M. B., Juillerat, M. A., and Cook, J. D. (2003). Degradation of phytic acid in cereal porridges improves iron absorption by human subjects. American Journal of Clinical Nutrition; 77: 1213-1219.

[47] Siegenberg, D., Baynes, R. D., Bothwell, T. H., Macfarlene, B. J., Lamparelli, R. D., Car, N. G., Macphail, P., Schmidt, U., Tal, A. and Mayet, F. (1991). Ascorbic acid prevents the dosedependent inhibitory effects of polyphenols and phytates on non-hemeiron absorption. American Journal of Clinical Nutrition; 53 (2): 537-554. 